\title{
Biogas Production from Rice Husk Waste by using Solid State Anaerobic Digestion (SSAD) Method
}

\author{
Hashfi Hawali Abdul Matin ${ }^{1, *}$ and Hadiyanto ${ }^{1,2}$ \\ ${ }^{1}$ Master Program of Environmental Science, School of Post Graduate Studies, Diponegoro University - Indonesia \\ ${ }^{2}$ Chemical Engineering Department, Engineering Faculty, Diponegoro University - Indonesia
}

\begin{abstract}
An effort to obtain alternative energy is still interesting subject to be studied, especially production of biogas from agriculture waste. This paper was an overview of the latest development of biogas researches from rice husk waste by Solid State Anaerobic Digestion (SSAD). The main obstacle of biogas production from rice husk waste was the lignin content which is very difficult degraded by microbes. Various pretreatments have been conducted, either physically, chemically as well as biologically. The SSAD method was an attractive option because of the low water content of rice husk waste. The biogas yield by SSAD method gave more attractive result compared to Liquid Anaerobic Digestion (LAD) method. Various studies were still conducted in batch mode laboratory scale and also has not found optimum operating conditions. Research on a larger scale such as bench and pilot scale with continuous systems will be an increase trend in the future research.
\end{abstract}

\section{Introduction}

Among of the global problems today is the issue of energy availability. The Indonesian government's efforts in addressing to cover this problem is by releasing the Government Regulation No 5/2006 about the use of new and renewable energy. Under this regulation, the Indonesian government targets to utilize new and renewable energy sources of $17 \%$ of the national energy mix in 2025 from the current of 5\%. Along with technological developments and the potential of natural resources, this target is raised to $25 \%$ in the new vision referred to as the $25 / 25$ vision. This effort can be classified in energy diversification and energy intensification.

Energy diversification means exploring new energy sources and renewable energy so as to obtain diverse types of which is energy from biomass which is often known as biogas, while intensifying the energy intended to make use of new energy as much as possible. As an agrarian country that also advanced in the field of industrialization, Indonesia has a very abundant biomass waste, including all industrial waste farms and livestock Biogas is an energy produced by organic matter fermented under anaerobic conditions [1]. Biogas is produced from renewable energy sources [2]. Biogas can be used as fuel for vehicles as well as for power and heat generation [3].

Biogas technology is actually not a new technology and this technology has been developed in Indonesia a few decades ago which is called first-generation biogas. Implementation technology of biogas production from livestock waste has also been done many researchers for decades. However, biogas production by anaerobic biodigester made from agricultural waste with a high lignocellulose content of Solid State Anaerobic Digestion (SS-AD) methods or called second generation biogas with pretreatment physical, chemical and biological methods with rumen bacterial biocatalyst is a breakthrough and the novelty of this biogas research.

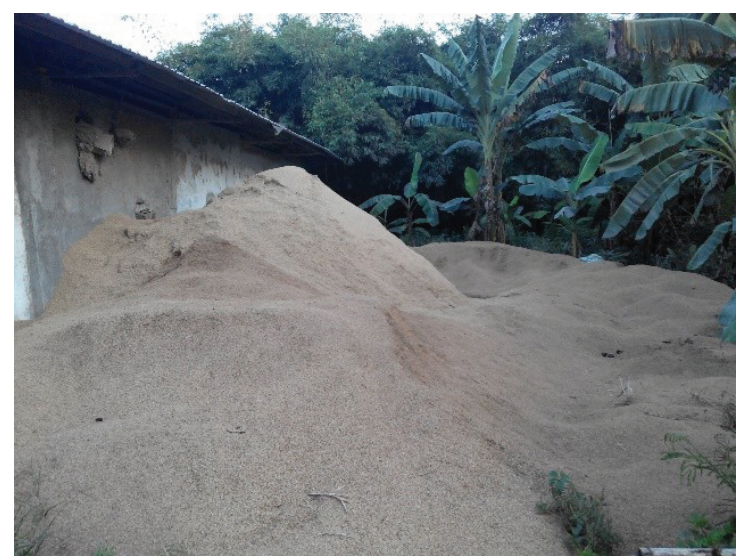

Fig 1. Rice Husk

Biogas production research from agricultural waste is rice husk is based on the abundance of rice husk existence especially in rural area and low utilization done. So far the utilization is done only as a mixing material of red bricks and planting media. Based on data collected from the Directorate of Food and Agriculture (2013), it can be seen that rice plants produce grain $(50 \%)$ and straw $(50 \%)$. Then from the grain can be produced brown rice $(80 \%)$ and husk $(20 \%)$. According

\footnotetext{
Corresponding author: hawalihashfi@gmail.com
} 
to Central Bureau of Statistics of Central Java Province in 2014 , rice crop productivity of $9,648,104.45$ Ton. So the total rice production in one year reaches $964,810.44$ Ton in 2014. It has excellent potential to be utilized as biogas. In addition, rice husk is very abundant also because of its difficulty to decompose because of high lignin content so it cannot be degraded by microorganisms easily. Through the preliminary treatment is expected to break down the content of lignin present in rice husks. The preliminary treatment may be physical, chemical and biological pretreatment [4].

In handling biogas production, utilizing anaerobic bacteria to produce methane gas $(\mathrm{CH} 4)$. In order to obtain the maximum biogas production results required the right conditions for methane-producing microorganisms to live and grow. Some of the things that affect the growth of microorganisms are temperature, $\mathrm{pH}$, alkalinity, $\mathrm{F} / \mathrm{M}$ ratio and $\mathrm{C} / \mathrm{N}$ ratio. The prospect of biogas technology development is very large, especially in rural areas where most of the people work in livestock and agriculture [2]. Biogas production technology, including SS-AD of rice husk waste biomass, should consider several parameters to produce optimal biogas.

The purpose of this article is to review the previous biogas research with rice husk waste materials through SSAD methods and to offer in-depth discussion on further research in order to obtain optimum operating conditions in batch or continuous scale.

\section{Characteristics of Rice Husk}

Agricultural waste is a biomass containing lignocellulose. Lignocellulose consists of cellulose, hemicellulose, lignin, extractive, and some inorganic materials. Table 1 shows the lignocellulosic components of various agricultural wastes. Cellulose, hemicellulose, and lignin are the three main components that are important sources for producing useful products, such as sugars from the fermentation process, chemicals and liquid fuels [5]. Lignocellulose can be obtained from wood, straw, rice husk, grasses, agricultural/forest wastes, industrial waste (wood, paper) and other fibrous materials [6].

Rice husk is one of agriculture waste containing lignocellulose which consists of $58.852 \%$ cellulose, $18.03 \%$ hemicellulose, lignin $20.9 \%$ and ash $0.16 \%$ $1 \%$. With a high amount of lignocellulosic content it is difficult to be degraded by microorganisms by itself. Usually farmers overcome rice husk waste by being burned and dumped. In fact, the way it can harm farmers and the surrounding environment because the combustion made to produce $\mathrm{CO} 2$ gas that is harmful to health. Meanwhile, landfill in the soil can be a contributing factor to the disease for the next crop. Therefore, in order to produce biogas from rice husk waste there is a need for special pretreatment before fermentation in the digester $[7,8]$.
Table 1. Lignocellulosic Components of Some Biomasses [9]

\begin{tabular}{lcccc}
\hline \multicolumn{1}{c}{ Biomass } & $\begin{array}{c}\text { Cellu- } \\
\text { lose (\%) }\end{array}$ & $\begin{array}{c}\text { Hemi- } \\
\text { cellulose }(\%)\end{array}$ & $\begin{array}{c}\text { Lignin } \\
(\mathbf{\%})\end{array}$ & $\begin{array}{c}\text { Ash } \\
(\mathbf{\%})\end{array}$ \\
\hline Rice husk & 58.852 & 18.03 & 20.9 & $0.16-1$ \\
Rice straw & $28-36$ & $23-28$ & $12-16$ & $15-20$ \\
Oil palm empty & $36-42$ & $25-27$ & $15-17$ & $0.7-6$ \\
bunches & & & & \\
Baggasse & $32-44$ & $27-32$ & $19-24$ & $1.5-5$ \\
Bamboo & $26-43$ & $15-26$ & $21-31$ & $1,7-5$ \\
Hardwood & $40-45$ & $7-14$ & $26-34$ & 1 \\
Softwood & $38-49$ & $19-20$ & $23-30$ & 1 \\
\hline
\end{tabular}

\section{Pretreatment Method}

\subsection{Chemical Pretreatment}

Chemical pretreatment refers to the use of chemicals, such as acids, bases, and ionic liquids to alter the physical and chemical characteristics of lignocellulosic biomass [10]. Despite many chemical pretreatment methods, only a few can be applied to the production of biogas in the anaerobic digestion process. The search of prior research with chemical pretreatment for biogas production is summarized in Table 2.

\subsection{Biological Pretreatment}

Microorganisms can be used for lignocellulosic pretreatment and increase enzymatic hydrolysis. Microorganisms are usually applied to degrade lignin and hemicellulose but very few parts of cellulose, because cellulose is more resistant than other parts of lignocellulose with biological treatment. The previous research search with biological pretreatment for biogas production is summarized in Table 3.

\subsection{Physical Pretreatment}

Pretreatment can physically increase surface area, reduce crystallinity and degree of cellulose polymerization [8]. Various types of physical processes such as grinding (eg ball milling, hammer milling, colloid milling) and irradiation (eg by gamma rays, electron beam or microwave) can be used to improve enzymatic hydrolysis or biodegradation of lignocellulosic waste materials. The previous research search with physical pretreatment for biogas production is summarized in Table 4.

\section{Solid State Anaerobic Digestion}

$\mathrm{AD}$ can be operated at different concentrations of different solids. AD processes with TS less than $15 \%$ are classified as liquid anaerobic digestion (L-AD), which is suitable for high water content wastes such as sewage and food waste [11]. So the L-AD needs a lot of water to handle low water waste such as lignocellulosiccontaining biomass. In contrast, solid state anaerobic digestion (SS-AD) operates on TS more than 15\% making it more suitable for digesting lignocellulose in biomass[11,12]. 


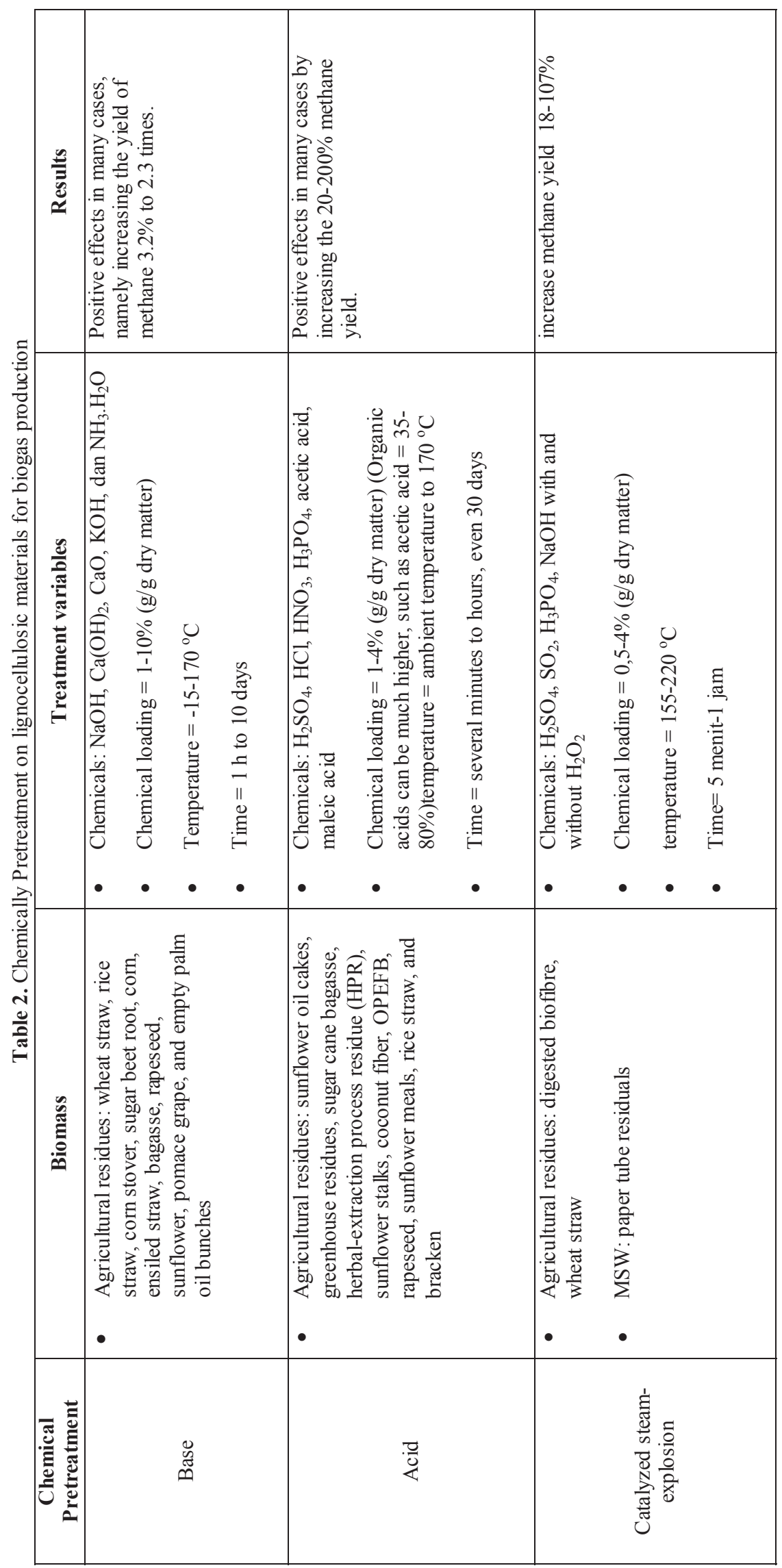



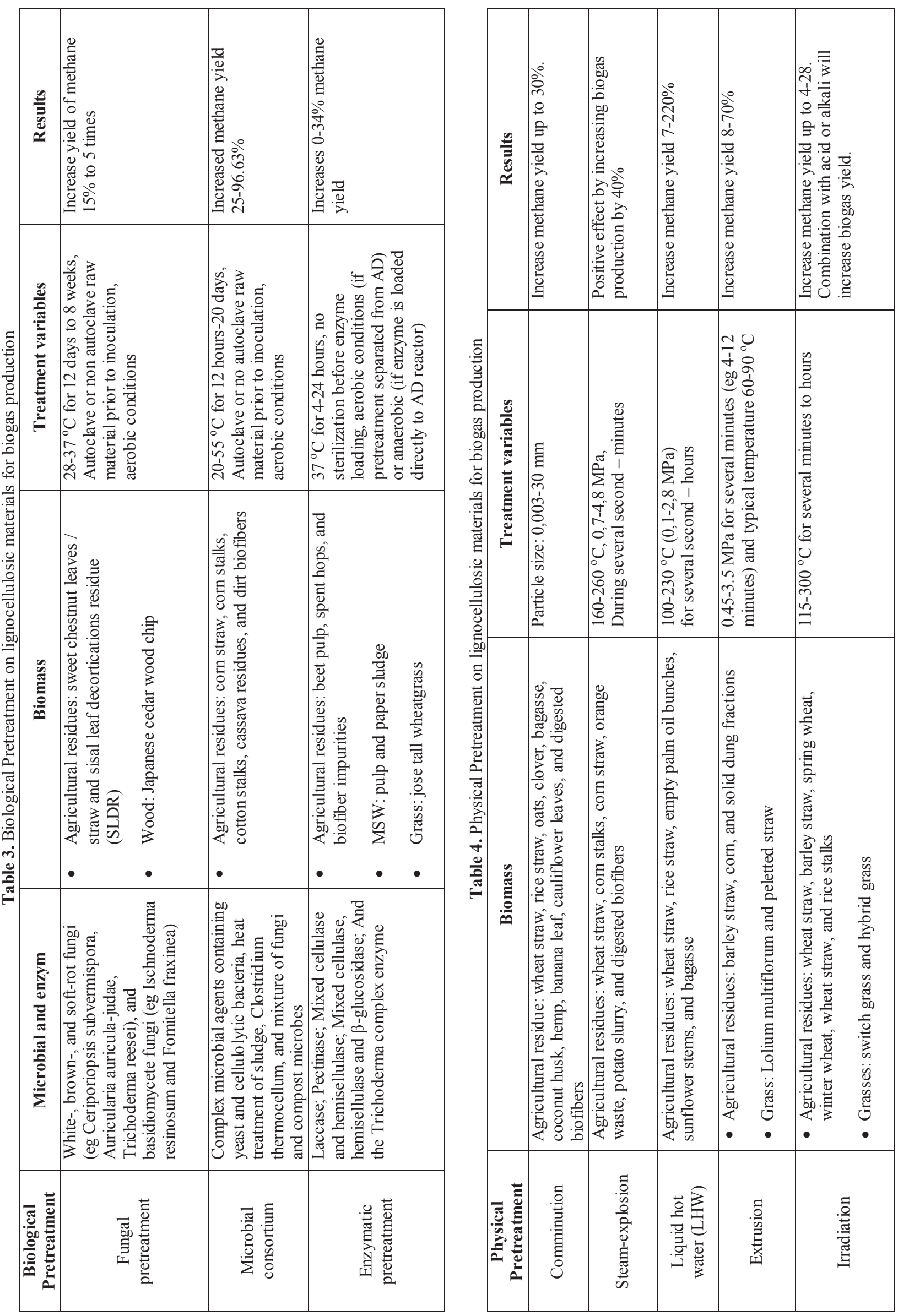
Compared to L-AD, SS-AD has several advantages such as higher methane volume productivity, low heating energy requirements and little waste water $[11,13]$. In America the SS-AD method has been used to convert organic waste that has a high solid content into biogas. Potential raw materials for SS-AD are lignocellulosic feedstocks, for example: food crops and forest products waste. In Europe the SS-AD system was used since the 1990s to cultivate municipal solid waste [14]. Here are the parameters that affect the SS-AD system.

\section{$4.2 \mathrm{pH}$}

The gas can be produced if the temperature is between 4$60{ }^{\circ} \mathrm{C}$ and the temperature is kept constant. The higher the reaction temperature will also be faster but the bacteria will decrease. Some bacteria can survive over a certain temperature range.

Temperature affects the anaerobic digestion process of organic matter and gas production. The digestion takes place either at a temperature of $30-40{ }^{\circ} \mathrm{C}$ for mesophilic conditions and at a temperature of $45-60^{\circ} \mathrm{C}$ for thermophilic conditions. The speed of fermentation decreases at temperatures below $20^{\circ} \mathrm{C}$. The optimal temperature of most mesophilic bacteria is achieved at $35^{\circ} \mathrm{C}$, but for thermophilic bacteria at $55^{\circ} \mathrm{C}$ [15].

Generally SS-AD can be operated under mesophilic conditions with temperatures between 20-45 ${ }^{\circ} \mathrm{C}$ or thermophilic conditions at temperatures of $45-65{ }^{\circ} \mathrm{C}$ [16]. At low temperatures, microorganisms in the fermentation process will produce fatty acids and alcohols because the methanogenic microorganisms are deactivated and thus cannot digest all the fermentation products that are formed. This results in a decrease in $\mathrm{pH}$ and the biogas production process stops [17]. While at high temperatures result in decreased biogas yield due to the formation of volatile gases such as ammonia which inhibits methanogenic activity $[18,19]$.

Comparison of thermophilic temperature with mesophilic is the activity of microorganism that produced $25-50 \%$ higher so as to produce more biogas yield. However, microorganisms in thermophilic conditions are more sensitive to temperature disturbances whereas at mesophilic temperatures microorganisms are more resistant to changes in environmental conditions [20]. Another disadvantage to thermophilic conditions is that it requires higher maintenance costs and less stable thermophilic digesters [21].

\subsection{Temperature}

The $\mathrm{pH}$ range of 7-7.5 is a neutral condition favored by most microorganisms. In the biogas process there are different types of microorganisms and $\mathrm{pH}$ for optimal growth of each microorganism [17]. The $\mathrm{pH}$ between 6.8-7.6 is the optimal condition for methanogenic bacteria and at $\mathrm{pH}$ below 6.6 the growth of methanogen bacteria will decrease, while the bacteria hydrolysis and acetogenesis can work at $\mathrm{pH}$ 5.5-6.6 [22]. If the $\mathrm{pH}$ value falls below 6.5 , then organic acid production by hydrolytic bacteria can lead to a more drastic decrease in $\mathrm{pH}$ and the fermentation process will stop [23]. The addition of sodium hydroxide or sodium bicarbonate can control the decrease in $\mathrm{pH}$ value [24]. If a $\mathrm{pH}$ value above 8.5 would inhibit the digestion process [25]. Methanogenic bacteria are bacteria sensitive to acidic conditions and bacterial growth may be inhibited under acidic conditions [26]. Based on these conditions, it was determined that the optimal $\mathrm{pH}$ of anaerobic digestion was between 6.8-8.0 [21].

\subsection{Alkalinity}

In the anaerobic system, there are two large groups of working microorganisms are acid-forming bacteria and methane forming bacteria. Both of these bacteria have very different in duplicate capabilities that is 3 hours for acid-forming bacteria and 3 days for bacteria forming methane. On the other hand, methane-forming bacteria are very sensitive to acidity or very sensitive with low $\mathrm{pH}$. This is very contradictory because at high feed load conditions tend to accelerate the occurrence of acid formation, thus lowering the $\mathrm{pH}$. This decrease in $\mathrm{pH}$ will disrupt the performance of methane-forming bacteria that have not yet developed [3].

Alkalinity is the number of base amounts in the reactor to neutralize the acidic conditions in the digester so that the $\mathrm{pH}$ of the digester is stable [20]. The presence of alkalinity in a reactor with a certain concentration can be a buffer (Buffer) to keep the $\mathrm{pH}$ in neutral conditions in the event of acid addition, so that the overall process balance can still run normally. When the $\mathrm{pH}$ is allowed to fall then the system will stop altogether because the methane-forming bacteria will die [3].

\subsection{Alkalinity}

In the anaerobic system, there are two large groups of working microorganisms are acid-forming bacteria and methane forming bacteria. Both of these bacteria have very different in duplicate capabilities that is 3 hours for acid-forming bacteria and 3 days for bacteria forming methane. On the other hand, methane-forming bacteria are very sensitive to acidity or very sensitive with low $\mathrm{pH}$. This is very contradictory because at high feed load conditions tend to accelerate the occurrence of acid formation, thus lowering the $\mathrm{pH}$. This decrease in $\mathrm{pH}$ will disrupt the performance of methane-forming bacteria that have not yet developed [3].

Alkalinity is the number of base amounts in the reactor to neutralize the acidic conditions in the digester so that the $\mathrm{pH}$ of the digester is stable [20]. The presence of alkalinity in a reactor with a certain concentration can be a buffer (Buffer) to keep the $\mathrm{pH}$ in neutral conditions in the event of acid addition, so that the overall process balance can still run normally. When the $\mathrm{pH}$ is allowed to fall then the system will stop altogether because the methane-forming bacteria will die [3]. 


\subsection{C/N Ratio}

Generally, 2/3 of carbon is regenerated into $\mathrm{CO} 2$ and the other $1 / 3$ is combined with nitrogen inside the cell. Microorganisms use N, P and other nutrients to make cell components but reduce organic $\mathrm{N}$ to organic acid and ammonia. Carbon from organic material not used in protein cells will be released especially to produce methane gas and less $\mathrm{CO} 2$ [27]. Nitrogen in the substrate has several advantages including providing essential elements for amino acid synthesis, neutralizing volatile acids produced by fermentation bacteria and also helping to attain neutral $\mathrm{pH}$. The amount of nitrogen should be within sufficient limits as a nutrient. While the optimum $\mathrm{C} / \mathrm{N}$ ratio for methane production is 20-35 [28].

The activity of microorganisms that play a role during the fermentation process depends on the $\mathrm{C} / \mathrm{N}$ ratio. In anaerobic digestion the optimal $\mathrm{C} / \mathrm{N}$ ratio is about 20-30 [11]. A high $\mathrm{C} / \mathrm{N}$ ratio in organic matter will result in lower methane production. This is because the material with high $\mathrm{C} / \mathrm{N}$ contains low levels of nitrogen. It causes rapid nitrogen consumption by methanogenic bacteria and results in biogas yields down due to the lack of nitrogen available for bacterial growth [8]. Therefore, to increase the level of nitrogen in the material can be done by adding organic materials containing high nitrogen such as livestock manure.

Meanwhile, if a very low $\mathrm{C} / \mathrm{N}$ ratio causes ammonia to accumulate and may raise the $\mathrm{pH}$ of the digester by 8.5 which is toxic to methanogenic bacteria [8]. Therefore, it is necessary to add other materials containing carbon or high fiber, such as grass, straw, husk and foliage. How to mix organic material with carbon-containing material to achieve the ratio of $\mathrm{C} / \mathrm{N}$ is determined. Here table $\mathrm{C} / \mathrm{N}$ ratio contained in some organic materials.

Table 5. C/N Ratio some Biomass [4]

\begin{tabular}{|l|c|}
\hline \multicolumn{1}{|c|}{ Biomass } & C/N Ratio \\
\hline Man manure & 8 \\
\hline Duck dung & 8 \\
\hline Chicken dung & 10 \\
\hline Goat dung & 12 \\
\hline Pig dung & 18 \\
\hline Sheep dung & 19 \\
\hline Buffalo/Cattle dung & 24 \\
\hline water hyac inth & 25 \\
\hline Elephant dung & 43 \\
\hline Corn Straw & 60 \\
\hline Rice Straw & 70 \\
\hline Wheat Straw & 90 \\
\hline Saw dust & $>200$ \\
\hline
\end{tabular}

\subsection{TS Content}

Water content is known as one of the important parameters that affect the anaerobic digestion process. Therefore, the total solid content is used to define two types of anaerobic digestion processes: wet digestion for TS $<15 \%$ and dry digestion for TS $>15 \%$ [29]. The total solid content affects the $\mathrm{pH}$ value and the effectiveness of microorganisms in the digestion process [30]. The total solid concentration in the SS-AD system is about $20-30 \%$. The total solid content (TS) of more than $30 \%$ can reduce biogas production by $17 \%$ due to the accumulation of organic acids and can decrease the substrate conversion $[29,31]$.

\subsection{Feedstock and Inoculum}

The substrate (feedstock) is converted to methane by anaerobic bacteria. Bacterial growth in the anaerobic digestion process can be accomplished by the addition of an inoculum or nutrient. This is because microorganisms need energy source to move on biogas production process. Nutrients required are macronutrients such as carbon, nitrogen, hydrogen, phosphorus, potassium and sulfur as well as micronutrients such as iron, copper, nickel, molybdenum, tungsten, cobalt and zinc [20].

Feedstock ratio to inoculum (F/I) is a parameter affecting SS-AD system in both batch and continuous process. In industrial SS-AD systems the F/I ratio is very low to avoid the risk of failure and maximize reaction kinetics [20]. The ratio of F/I used in the SS-AD system ranges from 2-6 [13].

\section{Conclusions}

Biogas production research from rice husk waste by SSAD method has been done by several researchers in laboratory scale. In the several study, an effort to increase biogas production were conducted the preliminary treatment of physics, chemistry and biology for the process of delignification. The activity aims to accelerate the fermentation process in the reactor by microorganisms. SSAD method is very suitable for agricultural waste, especially rice husk in terms of utilization as biogas because TS content is high so it does not require much water. According to some researchers, SSAD is able to produce more biogas than LAD. Through this overview, further research is needed on biogas from rice husk waste by SSAD method on a larger scale such as bench and pilot scale with continuous system.

\section{References}

1. Budiyono, I. Syaichurrozi, \& Sumardiono, S. Waste Tech, 1-5 (2013)

2. A. Saedi, Rutz, D. Prassl, H. Kottner, M. Finsterwalder, T. Volk, S. et al. Biogas. Denmark (2008)

3. D. Padmono, Kemampuan Alkalinitas Kapasitas Penyangga (Buffer Capacity) Dalam Sistem Anaerobik Fixed Bed, 8(2), 119-127 (2007)

4. B. R. Saragih, Magister Teknik Elektro, Fakultas Teknik Universitas Indonesia (2010)

5. A.T.W.M. Hendriks, G. Zeeman, Bioresource Technology, 100, 10-18 (2009) 
6. L. Appels, J. Lauwers, J. Degrève, L. Helsen, B. Lievens, K. Willems, Renew Sustain Energy Rev, 15, 4295-301 (2011)

7. N. Khorshidi, B. Arikan, Applied Biotechnology 181-300 ECTS credits No. 3 (2008)

8. M.J. Taherzadeh, K. Karimi, International Journal of Molecular Sciences, 9, 1621-1651 (2008)

9. M. Mulder, Basic Principles of Membrane Technology. 2nd Edition. Dordrecht Kluwer Academic (1996)

10. Y. Zheng, J. Zhao, F. Xu, Y. Li, Progress in Energy and Combustion Science pp. 35-53 (2014)

11. Y. Li, S.Y. Park, J. Zhu, Renewable and Sustainable Energy Reviews, 15(1), 821-826 (2011a)

12. L. Yang, Y. Li, Bioresource Technology, 171, 233239 (2014)

13. F. Xu, J. Shi, W. Lv, Z. Yu, Y. Li, Waste Management, 33(1), 26-32 (2013)

14. Y. Li, J. Zhu, C. Wan, S.Y. Park, American Society of Agricultural and Biological Engineers, 54(4), 1415-1421 (2011b)

15. S. Sahirman, Kajian Pemanfaatan Limbah Cair Pabrik Kelapa Sawit untuk Memproduksi Gasbio. Program Pascasarjana IPB : Bogor (1994)

16. L. $\mathrm{Yu}$, P.C. Wensel, J. Ma, S. Chen, Bioremediation \& Biodegradation (2013)

17. A. Schnürer, $\AA$. Jarvis, Swedish Waste Management and Swedish Gas Centre (2010)

18. B. Fezzani, C.R. Ben, Bioresource Technology, 101(6), 1628-34 (2010)
19. A. Khalid, M. Arshad, M. Anjum, T. Mahmood, L. Dawson, Waste Management, 31(8), 1737-44 (2011)

20. A. Teghammar, Chalmers University of Technology (2013)

21. J.C. Akwaka, D.T. Kukwa, S.S. Mwekave, International Journal of Science and Technology, 3(4), 222-228 (2014)

22. A.K. Jha, J. Li, L. Nies, L. Zhang, African Journal of Biotechnology, 10(65), 14242-14253 (2011)

23. D. Deublein, A. Steinhauser, Wiley-VCH Verlag GmbH dan Co. KGaA, Weinheim (2008)

24. P. Weiland, Appl Microbiol Biotechnol, 85, 849860 (2010)

25. Zeshan. Asian Institute of Technology, School of Environment, Resources and Development (2012)

26. K.M. Kangle, S.V. Kore, V.S. Kore and Kulkarni, G.S. Universal Journal of Environmental Research and Technology, 2(4), 210-219 (2012)

27. Gotaas, B. Harold, Sanitary Disposal and Reclamation of Organic Wastes (1956)

28. D. Enri. Jurnal Ilmiah dalam Seminar PAU Bioteknologi ITB (1990)

29. J.-C. Motte, R. Escudié, N. Bernet, J.-P. Delgenes, J.-P. Steyer, C. Dumas, Bioresource Technology, 144, 141-148 (2013)

30. N. Boontian, International Journal of Biological, Veterinary, Agricultural and Food Engineering, 66(9), 960-964 (2014)

31. A. Guendouz, A. Trably, E. Hamelin, J. Dumas, C. Steyer, J.P. Delgenès, J. Escudié, R. Bioresource Technology, 133, 256-262

(2013) 